\title{
Study of a Reading-Writing Project Based on Connectionism in China's EFL Classrooms
}

\author{
Qing $Y A N G^{1, a,{ }^{*}}$ and Wei $Y A O^{2, b}$ \\ ${ }^{1}$ Wuhan University of Technology, Wuhan City, Hubei Province, China \\ ${ }^{2}$ Wuhan University, Wuhan City, Hubei Province, China \\ asylviawut@126.com, ${ }^{b} 34075870 @ q q . c o m$
}

Keywords: Reading-writing project, Connectionism, Writing performance.

\begin{abstract}
Under the framework of connectionism, the present research designed a new syllabus - a reading-writing project for EFL students in a Chinese university. The project established a net for connection: reading materials as input units, self-reflection and peer discussion as hidden units, and writing as learners' output units. Over a semester, the quasi-experimental study concludes that the reading-writing project based on connectionism can motivate students to engage in writing and promote their writing performance.
\end{abstract}

\section{Introduction}

According to Kroll, reading has been traditionally regarded as a skill to be taught separately from writing. It's also something learners are expected to know beforehand when they attend the writing course. [1] Actually, reading and writing, the two skills are seldom taught together in class. Reading-writing integration is comparatively underexplored. In this article, a reading-writing integration project based on connectionism was set up for EFL learners in China in order to help students solve some problems existing in their writings. Furthermore, the study also attempted to investigate how the network activated learner's learning process and how the reading-writing project promoted EFL students' writing skills.

\section{Literature Review}

\section{Reading-Writing Integration}

Writing based on reading materials is a challenging task that even native learners have to study hard to acquire it. As to L2 learners, it also features as a major challenge, especially when their writing tasks are beyond their knowledge and lack of practice. According to some researchers, integration of reading and writing happens not only not very often in first language settings but also seldom in L2 settings.

The related studies can be divided into the following groups:

Firstly, there are a number of studies attempting to identify the academic reading and writing difficulties encountered by L2 learners by means of comparing with L1 learners [2]. Ferris [3] made a very detailed classification for the difficulties faced by L2 learners in academic settings.

Secondly, there are some studies involving the summary writing connected with reading. Yu [4] researched English summary writing with the subject of 157 Chinese L2 learners from universities and made the conclusion that participants' writing abilities were significantly related to their reading proficiency levels. In addition, Baba [5], after 
examined 68 L2 learners from Japanese universities, concluded that participants' writing abilities were correlated to both reading comprehension skill and vocabulary knowledge.

Thirdly, the effects of the reading-writing integration instruction on students' writing were studied. Zhang [6] carried out a 15-week study with EAP students under the different instructions. The experimental group was found through comparison significantly outperformed the control group in writing and better use of information from reading materials.

\section{E. L. Thorndike's Theory of Connectionism in Educational Psychology}

Connectionism applied in education and learning theory was coined by Edward Lee Thorndike (1874-1949), American psychologist, educator, lexicographer and also a pioneer in the adult education movement. He integrated in his research animal behavior and the learning process, which led to the theory of connectionism. He believes that the psychology is the coupling system of human being, and learning is the connection between settings and reactions. Through the experimental study, Thorndike asserts that, no matter what kind of form of learning is, it is in fact to form the connection between a scenario and a particular reaction so that the connection strength is enhanced. His theory has been well put forward by Hadley and other researchers during 1990s. Shultz [7] and Karadut [8] attempted to apply Thorndike's theory in practical classroom instruction, and found positive effects on the improvement of students' learning. Connectionism learning model combines cognition and learning. So far, the relevant practical researches are comparatively few, especially the ones relating to the educational research.

Based on the connectionist models, the study established a net for connection: reading materials as input units, self-reflection and peer discussion as hidden units, writing production as learners' output units, as well as mechanics for reinforcing stimulus and punishing stimulus.

\section{Methodology}

\section{Participants}

As is shown in Table 1, all participants, aged from 18-21, were randomly selected 56 EFL college undergraduate students in a Chinese university of Technology. The participants come from the same grade levels and at the same proficiency level—all are first-year students in B-level class. None of them have participated in the specialized English writing course before. All the students were divided into two classes randomly, with 28 participants in the experiment and control group respectively.

\section{Instruction Treatment}

Under the framework of connectionism, the research designed a new syllabus - a reading-writing project for the experimental class. The project established a net for connection: reading materials as input units, self-reflection and peer discussion as hidden units, and writing as learners' output units. The experiment class followed the reading-writing project designed based on connectionism over one semester. The control group, instructed with the traditional approach, was taught in the routine process of lead-in, text explanation and exercises. 


\section{Data Collection}

To describe the changes and improvement made by Chinese EFL students in their writing affected by the two approaches, timed compositions were collected within a class period (30 minutes). At the beginning and in the end of the course, the students were required to write an argumentation on the same topic within 30 minutes as the pretest and posttest for the course. On the other hand, prior knowledge can have a significant impact on the quality of writing. Therefore, the selected topics of article were acquainted by all the students, with the hope to minimize differences in their prior knowledge during writing. To ensure that all the students could regard the writing carefully and seriously, they were informed that the scores of their writings would be a part of the final score of the course.

Table 1. Demographic characteristics of the participants

\begin{tabular}{|c|c|c|c|}
\hline Characteristic & Value & Frequency & Percent \\
\hline \multirow{2}{*}{ Gender } & Male & 43 & 77 \\
\cline { 2 - 4 } & Female & 13 & 23 \\
\hline Grade & Freshmen & 56 & 100 \\
\hline Class Level & B-class & 56 & 100 \\
\hline Proficiency Level & Passing CET 4 & 0 & 0 \\
\hline Age Group & 18 & 9 & 16 \\
\cline { 2 - 4 } & 19 & 19 & 34 \\
\cline { 2 - 4 } & 20 & 25 & 5 \\
\cline { 2 - 4 } & 21 & 3 & 7 \\
\hline Years of English & 8 & 4 & 46 \\
\cline { 2 - 4 } Learning & 9 & 26 & 36 \\
\cline { 2 - 4 } & 10 & 20 & 11 \\
\cline { 2 - 4 } & More than 10 & 6 & 5 \\
\hline
\end{tabular}

\section{Data Analysis}

All the compositions were coded and scored based on Warren's Scoring criteria with a five point scale (Scores 0-4). They are thesis, content and development, research and support, structure, language and mechanics. Sub-scores were evaluated on the five point scale.

In order to avoid the mistakes in counting, the above jobs were undertaken by 3 experienced EFL raters. 2 raters scored each essay after the test. The 3rd read was conducted when scores were 2 points different (90\% interrater reliability). All the score data collected were typed into computer and analyzed in SPSS.

\section{Results \& Discussions}

\section{Results for Comparisons on Writing Scores within the Experiment Group}

\section{Comparisons on Holistic Scores within the Experiment Group}

With the purpose to test the effect of the reading-writing project on students' writing, the scores of the pretest and posttest were analyzed by Paired Sample T-Test. The Results for comparisons on holistic scores within the experiment group were shown in Table 2 and Table 3.

Table 2. Descriptive statistics

\begin{tabular}{|c|c|c|c|c|c|}
\hline \multicolumn{2}{|l|}{} & Mean & N & Std. Deviation & Std. Error Mean \\
\hline Pair 1 & pretest & 10.0000 & 28 & 1.58698 & .29991 \\
\hline & posttest & 13.2143 & 28 & 1.10075 & .20802 \\
\hline
\end{tabular}


Table 3. Paired samples test

\begin{tabular}{|c|c|c|c|c|c|c|c|c|c|}
\hline & & \multicolumn{5}{|c|}{ Paired Differences } & \multirow[t]{2}{*}{$\mathrm{t}$} & \multirow[t]{2}{*}{ df } & \multirow[t]{2}{*}{$\begin{array}{c}\text { Sig. } \\
\text { (2-tailed) }\end{array}$} \\
\hline & & Mean & $\begin{array}{c}\text { Std. } \\
\text { Deviatio } \\
\mathrm{n}\end{array}$ & $\begin{array}{c}\text { Std. } \\
\text { Error } \\
\text { Mean }\end{array}$ & $\begin{array}{r}95 \% \mathrm{Cc} \\
\text { Interv } \\
\text { Diff }\end{array}$ & $\begin{array}{l}\text { fidence } \\
\text { of the } \\
\text { ence }\end{array}$ & & & \\
\hline $\begin{array}{c}\text { Pair } \\
1\end{array}$ & $\begin{array}{l}\text { pretest -- } \\
\text { posttest }\end{array}$ & -3.21429 & 1.54817 & .29258 & -3.81460 & -2.61397 & $\begin{array}{l}-10 . \\
986\end{array}$ & 27 & .000 \\
\hline
\end{tabular}

According to Table 2, with the difference at 0.000 level which is much less than 0.05 , pretest and posttest scores of the experiment group have significant differences. Seen from Table 2, posttest scores with mean score of 13.2143 are comparatively much higher than the pretest scores with mean score of 10.0000, which indicates that students improve their writing performance during the study after one semester's learning based on the project. Namely, the new instruction approach has positive effect on students' writing performance.

Comparison on the 5 Items of Evaluation within the Experimental Group

Table 4. Paired samples test

\begin{tabular}{|c|c|c|c|c|c|c|c|c|c|}
\hline & & \multicolumn{5}{|c|}{ Paired Differences } & \multirow[t]{3}{*}{$\mathrm{t}$} & \multirow[t]{3}{*}{ df } & \multirow[t]{3}{*}{$\begin{array}{c}\text { Sig. } \\
\text { (2-tailed) }\end{array}$} \\
\hline & & \multirow[t]{2}{*}{ Mean } & \multirow[t]{2}{*}{$\begin{array}{c}\text { Std. } \\
\text { Deviatio } \\
\mathrm{n}\end{array}$} & \multirow[t]{2}{*}{$\begin{array}{l}\text { Std. } \\
\text { Error } \\
\text { Mean }\end{array}$} & \multicolumn{2}{|c|}{$\begin{array}{l}\text { 95\% Confidence } \\
\text { Interval of the } \\
\text { Difference }\end{array}$} & & & \\
\hline & & & & & Lower & Upper & & & \\
\hline $\begin{array}{l}\text { Pai } \\
\text { r } 1\end{array}$ & $\begin{array}{l}\text { ThesisE1 - } \\
\text { ThesisE2 }\end{array}$ & -.10714 & .31497 & .05952 & -.22928 & .01499 & -1.800 & $\begin{array}{l}2 \\
7\end{array}$ & .083 \\
\hline $\begin{array}{l}\text { Pai } \\
\text { r } 2\end{array}$ & $\begin{array}{c}\text { contentE1 - } \\
\text { contentE2 }\end{array}$ & -.78571 & .49868 & .09424 & -.97908 & -.59235 & -8.337 & $\begin{array}{l}2 \\
7\end{array}$ & .000 \\
\hline $\begin{array}{l}\text { Pai } \\
\text { r } 3\end{array}$ & $\begin{array}{c}\text { supportE1 - } \\
\text { supportE2 }\end{array}$ & $\begin{array}{c}-1.2142 \\
9\end{array}$ & .56811 & .10736 & -1.43458 & -.99399 & $\begin{array}{c}-11.31 \\
0\end{array}$ & $\begin{array}{l}2 \\
7\end{array}$ & .000 \\
\hline $\begin{array}{l}\text { Pai } \\
\text { r } 4\end{array}$ & $\begin{array}{c}\text { structureE1 } \\
- \\
\text { structureE2 }\end{array}$ & -.39286 & .49735 & .09399 & -.58571 & -.20001 & -4.180 & $\begin{array}{l}2 \\
7\end{array}$ & .000 \\
\hline $\begin{array}{l}\text { Pai } \\
\text { r } 5\end{array}$ & $\begin{array}{c}\text { LanguageE } \\
1- \\
\text { LanguageE } \\
2\end{array}$ & -.57143 & .63413 & .11984 & -.81732 & -.32554 & -4.768 & $\begin{array}{l}2 \\
7\end{array}$ & .000 \\
\hline
\end{tabular}

Aiming to find out the more detailed improvement in participants writing, the comparison on the five points of evaluation was conducted. The Paired Samples Test results in Table 4 display that significant differences were found for content, support, structure and language variables, with significance level of 0.000 which much less than 0.05 . Students made great improvement on the content, support, structure and language in their writing. No difference was found on Thesis $($ sig. $=.083>0.05$ ).

\section{Comparisons between the Experiment and Control Group}

\section{Comparison on Holistic Scores of the Experiment Group}

In order to reflect the difference between the two teaching methods and the effect of the reading-writing project on students writing, means comparison test between the experiment and control group was conducted. 
Table 5. Report scores

\begin{tabular}{|c|c|c|c|}
\hline \multicolumn{2}{|c|}{$\begin{array}{c}\text { Method (Method 1: reading-writing project } \\
\text { Method 2: traditional teaching) }\end{array}$} & pretest & posttest \\
\hline 1.00 & Mean & 10.0000 & 13.2143 \\
\hline & $\mathrm{N}$ & 28 & 28 \\
\hline & Std. Deviation & 1.58698 & 1.10075 \\
\hline 2.00 & Mean & 9.6786 & 10.4643 \\
\hline & $\mathrm{N}$ & 28 & 28 \\
\hline & Std. Deviation & 2.40453 & 2.44165 \\
\hline Total & Mean & 9.8393 & 11.8393 \\
\hline & $\mathrm{N}$ & 56 & 56 \\
\hline & Std. Deviation & 2.02509 & 2.33376 \\
\hline
\end{tabular}

Table 6. ANOVA table

\begin{tabular}{|c|c|c|c|c|c|c|}
\hline \multicolumn{2}{|c|}{} & Sum of Squares & df & Mean Square & F & Sig. \\
\hline Pretest & Between Groups & 1.446 & 1 & 1.446 & .349 & .557 \\
\hline & Within Groups & 224.107 & 54 & 4.150 & & \\
\hline & Total & 225.554 & 55 & & & \\
\hline Posttest & Between Groups & 105.875 & 1 & 105.875 & 29.519 & .000 \\
\hline & Within Groups & 193.679 & 54 & 3.587 & & \\
\hline & Total & 299.554 & 55 & & & \\
\hline
\end{tabular}

From Table 5 and Table 6 , significant difference was found on posttest scores of the experiment group (sig. $=.000<0.05$ ). As for pretest score, with sig $0.557>0.05$, no significant difference was presented.

Comparison on the 5 Items of Evaluation between Groups

Table 7. Paired samples test for pretest score of two groups

\begin{tabular}{|c|c|c|c|c|c|c|c|c|c|}
\hline & & \multicolumn{5}{|c|}{ Paired Differences } & \multirow[t]{3}{*}{$\mathrm{t}$} & \multirow[t]{3}{*}{$\mathrm{df}$} & \multirow[t]{3}{*}{$\begin{array}{c}\text { Sig. } \\
\text { (2-tailed) }\end{array}$} \\
\hline & & \multirow[t]{2}{*}{ Mean } & \multirow[t]{2}{*}{$\begin{array}{c}\text { Std. } \\
\text { Deviation }\end{array}$} & \multirow[t]{2}{*}{$\begin{array}{l}\text { Std. } \\
\text { Error } \\
\text { Mean } \\
\end{array}$} & \multicolumn{2}{|c|}{$\begin{array}{l}95 \% \text { Confidence } \\
\text { Interval of the } \\
\text { Difference }\end{array}$} & & & \\
\hline & & & & & Lower & Upper & & & \\
\hline $\begin{array}{c}\text { Pair } \\
1\end{array}$ & $\begin{array}{l}\text { ThesisE1 - } \\
\text { ThesisC1 }\end{array}$ & .17857 & .72283 & $\begin{array}{c}.1366 \\
0\end{array}$ & -.10171 & $\begin{array}{c}.4588 \\
6\end{array}$ & 1.307 & 27 & .202 \\
\hline $\begin{array}{c}\text { Pair } \\
2\end{array}$ & $\begin{array}{l}\text { contentE1 - } \\
\text { content } \mathrm{C} 1\end{array}$ & $\begin{array}{c}-.1071 \\
4\end{array}$ & .62889 & .1188 & $\begin{array}{c}-.35100 \\
5\end{array}$ & $\begin{array}{c}.1367 \\
2\end{array}$ & -.902 & 27 & .375 \\
\hline $\begin{array}{l}\text { Pair } \\
3\end{array}$ & $\begin{array}{l}\text { supportE1 - } \\
\text { support C1 }\end{array}$ & $\begin{array}{c}-.2500 \\
0\end{array}$ & .75154 & $\begin{array}{c}.1420 \\
3\end{array}$ & -.54142 & $\begin{array}{c}.0414 \\
2\end{array}$ & -1.760 & 27 & .090 \\
\hline $\begin{array}{c}\text { Pair } \\
4\end{array}$ & $\begin{array}{l}\text { structureE1 - } \\
\text { structure C1 }\end{array}$ & .14286 & .59094 & $\begin{array}{c}.1116 \\
8\end{array}$ & -.08628 & $\begin{array}{c}.3720 \\
0\end{array}$ & 1.279 & 27 & .212 \\
\hline $\begin{array}{l}\text { Pair } \\
5\end{array}$ & $\begin{array}{l}\text { LanguageE1 - } \\
\text { Language C1 }\end{array}$ & .21429 & .95674 & $\begin{array}{c}.1808 \\
1\end{array}$ & -.15670 & $\begin{array}{c}.5852 \\
7\end{array}$ & 1.185 & 27 & .246 \\
\hline
\end{tabular}

As shown in Table 7 and Table 8, no significant difference was found in terms of thesis, content, support, structure and language for the pretest score of two groups. While significant differences were presented for content, support, structure and language for the posttest score of two groups. Although the differences in terms of structure and language with sig 0.03 and 0.026 respectively are comparatively smaller than that of content and support with sig 0.000 . 
Table 8. Paired samples test for posttest score of two groups

\begin{tabular}{|c|c|c|c|c|c|c|c|c|c|}
\hline & & \multicolumn{5}{|c|}{ Paired Differences } & \multirow[t]{3}{*}{$\mathrm{t}$} & \multirow[t]{3}{*}{ df } & \multirow[t]{3}{*}{$\begin{array}{c}\text { Sig. } \\
\text { (2-tailed) }\end{array}$} \\
\hline & & \multirow[t]{2}{*}{ Mean } & \multirow[t]{2}{*}{$\begin{array}{c}\text { Std. } \\
\text { Deviation }\end{array}$} & \multirow[t]{2}{*}{$\begin{array}{l}\text { Std. } \\
\text { Error } \\
\text { Mean } \\
\end{array}$} & \multicolumn{2}{|c|}{$\begin{array}{l}\text { 95\% Confidence } \\
\text { Interval of the } \\
\text { Difference }\end{array}$} & & & \\
\hline & & & & & Lower & Upper & & & \\
\hline $\begin{array}{l}\text { Pai } \\
\text { r } 1\end{array}$ & $\begin{array}{l}\text { ThesisE2 - } \\
\text { ThesisC2 }\end{array}$ & .14286 & .75593 & .14286 & -.15026 & .43598 & 1.000 & 27 & .326 \\
\hline $\begin{array}{l}\text { Pai } \\
\text { r } 2\end{array}$ & $\begin{array}{l}\text { contentE2 - } \\
\text { content } \mathrm{C} 2\end{array}$ & .64286 & .82616 & .15613 & .32251 & .96321 & 4.117 & 27 & .000 \\
\hline $\begin{array}{l}\text { Pai } \\
\text { r } 3\end{array}$ & $\begin{array}{l}\text { supportE2 - } \\
\text { support C2 }\end{array}$ & 1.21429 & .73822 & .13951 & .92803 & $\begin{array}{c}1.5005 \\
4 \\
\end{array}$ & 8.704 & 27 & .000 \\
\hline $\begin{array}{l}\text { Pai } \\
\text { r } 4\end{array}$ & $\begin{array}{c}\text { structureE2 } \\
\text { - structure } \\
\text { C2 }\end{array}$ & .35714 & .82616 & .15613 & .03679 & 67749 & 2.287 & 27 & .030 \\
\hline $\begin{array}{l}\text { Pai } \\
\text { r } 5\end{array}$ & $\begin{array}{c}\text { LanguageE2 } \\
\text { - Language } \\
\text { C2 }\end{array}$ & .32143 & .72283 & .13660 & .04114 & .60171 & 2.353 & 27 & .026 \\
\hline
\end{tabular}

\section{Discussion}

\section{Comparisons on Writing Scores within the Experiment Group}

As shown in Table 3, pretest and posttest scores of the experiment group have significant differences (sig. $=0.000<0.05$ ). According to Table 2 , posttest scores are comparatively much higher than the Pretest scores. It proves that the experiment group had made great progress in writing performance after one semester's teaching interference under the reading-writing project.

Table 4 well illustrated the improvement distribution, significant differences were found in terms of content, support, structure and language variables (sig. $=0.000<0.05$ ). Students made great improvement on the content, support, structure and language in their writing. No difference was found on Thesis $($ sig. $=.083>0.05$ ). The results indicated that the reading-writing project promoted the improvement of content, support, structure and language in students' writing. Students in the experimental class developed positive attitudes towards the writing process and were able to apply input information in their writings. In addition, the comparison within the pretest and post-test of experimental class showed that scores for content changed the most. Those of language, structure ranked the second and the third. The experiment group applied more supporting arguments, examples in their post-test writings which are also better and more varied in content.

\section{Comparisons between the Experiment and Control Group}

From Table 5 and Table 6, referring to pretest score $(0.557>0.05)$, no significant difference was presented. There is no significant difference at the beginning of experiment. After one semester study, the significant difference was shown between two groups on posttest scores (sig. $=.000<0.05)$. The Experiment group made great improvement in contrast to the control group.

After compared the five points of evaluation between groups, the result indicated that the reading-writing project promoted the improvement of content, support, structure and language in students' writing. The content of the experiment groups' writings became better and with diversified information. The development of content tended to 
be more related to thesis. Supporting details of the experiment groups' writings were improved as well. Students could apply various styles of supporting details besides the style of personal experience. The Structure in the writings of the experiment groups changed from the formulated style to variety. The Language applied in the posttest writing of the experiment group became more accurate. Many problems have been solved such as punctuation and capitalization problem. Students applied more compound/complicated sentences.

\section{Conclusion}

This experimental study investigated how the network activated learner's learning process and how the reading-writing project promoted EFL students' writing skills. After one semester experiment, the present study concluded that the reading-writing project in the framework of connectionism can motivate students to engage in writing and promote their writing performance, which accords with Shultz's [7] and Karadut's [8] findings. These findings can help promote the writing instruction based on reading-writing project for Chinese EFL learners and provide insights into the role of connectionism in L2 writing. However, instruction approach design should make strict regulations and control upon the order of reaction, and form students' writing habit through constant practice. Attention should also be paid to the students in the process of practice - whether they are fatigued and bored; and paid to the difficulty level of reading and writing content, in order not to make the students feel frustrated and be discouraged. Therefore, further research need conducting to help improve the project design.

\section{Acknowledgement}

This research was financially supported by Governmental Research Funds from People's Government of HuBei Province (Grant NO. HBZFFZYJ2015014).

\section{References}

[1] B. Kroll, Teaching writing is teaching reading: Training the new teacher of ESL composition, in: J.G. Carson, \& I. Leki (Eds.), Reading in the Composition Classroom: Second Language Perspectives, MA: Heinle \& Heinle Publishers, Boston, 1993, pp. 61-81.

[2] B. Paltridge, \& S. Starfield, Thesis and Dissertation Writing in a Second Language, Routledge Falmer, London, 2007.

[3] D. Ferris, Teaching college writing to diverse student populations, University of Michigan Press, Ann Arbor, 2009.

[4] G. Yu, Reading to summarize in English and Chinese: A tale of two languages? Language Testing, 25 (2008) 521-551.

[5] K. Baba, Aspects of lexical proficiency in writing summaries in a foreign language, Journal of Second Language Writing, 18 (2009) 191-208.

[6] C. Zhang, Effect of instruction on English as a second language students! Discours esynthesis writing (Doctoral dissertation), Available from Pro Quest Dissertation and Theses database, (Accession No. 3370640) 2012. 
[7] T.R. Shultz, Connectionism and Learning, in: International Encyclopedia of Education, third ed., 2010, pp. 476-484.

[8] Karadut, Effects of E. L. Thorndike's theory of connectionism rudiments on developing cello playing skills for beginners, Procedia-Social and Behavioral Sciences, 69 (2012) 298-305. 